\title{
Cystadenoma: a rare tumor originated in minor salivary gland
}

\author{
Cistadenoma: um tumor raro em glândula salivar menor
}

Jean Nunes dos Santos'; Adna Conceição Barros'² Viviane Almeida Sarmento ${ }^{3}$; Clarissa Araújo Silva Gurgel ${ }^{4}$; Veronica Ferreira de Souza ${ }^{5}$

\begin{tabular}{|c|c|}
\hline key words & abstract \\
\hline $\begin{array}{l}\text { Benign neoplasm } \\
\text { Cystadenoma } \\
\text { Buccal mucosa }\end{array}$ & $\begin{array}{l}\text { Cystadenoma of salivary glands is an uncommon benign neoplasm that presents intraluminal papillary } \\
\text { projections. The authors describe one case of cystadenoma located in the buccal mucosa and highlight its } \\
\text { histomorphological features and differential diagnosis. }\end{array}$ \\
\hline Minor salivary gland & \\
\hline Differential diagnosis & \\
\hline
\end{tabular}

resumo

O cistadenoma de glândula salivar é uma neoplasia benigna incomum, que exibe projeções papilíferas intraluminais. Os autores descrevem um caso de cistadenoma localizado na mucosa jugal, discutindo os aspectos histomorfológicos e o diagnóstico diferencial desse tumor.
Primeira submissão em 01/06/07 Última submissão em 27/02/08 Aceito para publicação em 27/02/08 Publicado em 20/06/08

Differential diagnosis 


\section{Case report}

AMRJ, a 67-year-old woman, was referred by her prosthetic dentist to the Dental School of Universidade Federal da Bahia (UFBA) due to the presence of a submucosal nodule located on the right side of the buccal mucosa. During anamnesis, the patient reported to have never seen the lesion, which was completely asymptomatic and was only discovered upon routine examination. The nodule measured approximately $1.5 \mathrm{~cm}$ in its maximum diameter and was covered with intact mucosa. An excisional biopsy was performed under the clinical suspicion of mucocele. Histopathological analysis revealed a benign tumor of glandular epithelial origin, which was characterized by epithelial cells arranged in multiple cystic spaces of variable size, often exhibiting intraluminal papillary proliferations (Figures 1A and 1B). The cystic spaces were lined with cells arranged in a double layer, i.e. a basal layer of cuboidal cells and an overlying layer of tall columnar cells (Figure 1C). These cellular arrangements were often found to be hyperplastic, and eventually exhibited squamous or oncocytic metaplasia (Figure 1D). Scarce fibrovascular tissue lacking a lymphocytic component surrounded the described spaces. Ectatic glandular ducts containing a hematoxyphilic fluid were observed by the side of the lesion, as well as extensive lobules consisting of mucous acini infiltrated by lymphocytes. The established diagnosis was papillary cystadenoma. The patient is currently being followed up and shows no signs of recurrence.

\section{Discussion}

Cystadenoma of the salivary glands is a rare benign epithelial tumor, which is predominantly characterized by multicystic growth, exhibiting papillary and, less frequently,

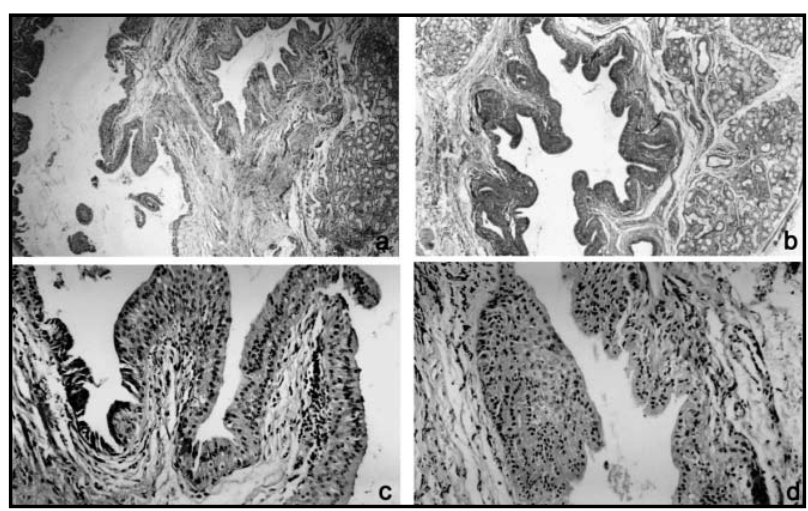

Figure 1 - A: Microcysts and well differentiated mucous acini ( $H \& E x 40)$; B: cystic cavity exhibiting papillary projections supported by fibrous connective tissue ( $H \& E \times 100)$; C: papillary projection lined by tall columnar cells (H\&E X400); D: papillae showing oncocytic metaplasia (H\&E x400) mucinous proliferation ${ }^{(4,18)}$. Cystadenoma presents no distinct clinical features and closely resembles mucocele ${ }^{(15)}$, as initially diagnosed in the present case. The tumor is more frequent in the minor salivary glands, although cases occurring in the major glands, such as the parotid gland, have been reported ${ }^{(5,9,15)}$. In the present case, the tumor presented as an asymptomatic nodule in the buccal mucosa, and measured on average $1.5 \mathrm{~cm}$ in its maximum diameter. These features agree with those reported in literature ${ }^{(4,5,12,24)}$. However, cases of cystadenoma affecting other sites, such as the lips and the palate, have also been described $(7,10,12,14,22)$.

Cystadenoma frequently affects patients in the sixth decade of life, with a female:male ratio of $3: 1^{(5)}$. The present case was a woman in the seventh decade of life, as also reported.

Histologically, in the present case the tumor manifested as a benign lesion of glandular epithelial origin characterized by epithelial cells arranged in multiple cystic spaces of variable size, often exhibiting intraluminal papillary proliferations. The cystic spaces were lined with a double layer of cells lacking atypias, with the basal layer consisting of cuboidal cells and the overlying layer of tall columnar cells. Squamous or oncocytic metaplasia was sometimes observed, and the presence of an inflammatory infiltrate was a common feature in some areas. These histopathological patterns agree with those defined for cystadenoma ${ }^{(1,5,7,15,22)}$, and the lesion was therefore diagnosed as cystadenoma. However, in view of the complexity and histomorphological diversity of salivary gland tumors, the differential diagnosis of cystadenoma should include intraductal papilloma ${ }^{(19)}$, cystadenocarcinoma ${ }^{(6)}$, lowgrade mucoepidermoid carcinoma ${ }^{(17)}$, Warthin tumor ${ }^{(1)}$ and cheilitis glandularis ${ }^{(20)}$, which are discussed below.

Intraductal papilloma always occurs in a single cystic space and is characterized by numerous and complex papillary projections ${ }^{(19)}$. These features were not observed in the present case. Especially in our case, the tumor consisted of multiple cystic spaces lined with a double layer of cells exhibiting intraluminal papillary proliferation.

Although rare in the oral mucosa, cystadenocarcinomas are morphologically similar to cystadenomas, a fact that tends to make diagnosis difficult. However, some aspects distinguish cystadenocarcinoma from cystadenoma, such as mode of invasion, pattern of solid growth in focal areas, cellular atypia in some cases, permeation or destruction of the glandular parenchyma, and breakdown of the glandular lobe architecture, as well as infiltration of adipose, muscle or bone tissues ${ }^{(6)}$. None of these features was observed in the present case. 
Similar to cystadenocarcinoma, low-grade mucoepidermoid carcinoma also requires a more in-depth criterion for assessment because it is an infiltrating malignant neoplasm ${ }^{(17)}$ that resembles cystadenoma in terms of the growth pattern and the cell population involved. In this respect, mucoepidermoid carcinoma presents, in addition to cystic structures, non-cystic epithelial proliferations, a feature that is very important in the distinction between both types of neoplasms. When present, papillary growth is irregular and complex, as observed in intraductal papilloma. Regarding the cell population, low-grade mucoepidermoid carcinoma exhibits a combination of epidermoid, mucosal and, to a lesser extent, intermediate and basaloid cells ${ }^{(5)}$.

On the other hand, Warthin tumor (lymphomatous papillary cystadenoma) is characterized by an epithelium of often oncocytic origin, which shows multiple papillary proliferations projecting into the cystic spaces, supported by a lymphoid stroma, and should not be confused with cystadenoma or other tumors $^{(1,2,5)}$. In the present case cystadenoma did not show a marked inflammatory infiltrate, but only scarce inflammatory cells.

In contrast, cheilitis glandularis represents an inflammatory alteration of the lower lip of unknown etiology, which might be diagnosed as a neoplasm. In 2003, a case of this lesion was described, what was initially diagnosed as papillary cystadenoma since an incisional biopsy showed a lesion of papillary arrangement that exhibited marked oncocytic ductal hyperplasia and squamous metaplasia ${ }^{(20)}$. However, the clinical aspect in that case strongly contributed to the diagnosis of the initial phase of cheilitis glandularis since the lesion clinically manifested as multiple nodules in the lower lip, as reported for a simple subtype. In the present case, the location of the tumor differed from that described for cheilitis glandularis, and the tumor clinically manifested as a single nodule.

In most cases of cystadenoma, the recommended treatment is simple surgical excision ${ }^{(11,12,15,22)}$, although follow-up of the patient is necessary since recurrences due to incomplete excision have been reported ${ }^{(1)}$.

\section{Acknowledgments}

We are grateful to FAPESB, for grant $122 / 07$, and to Maria de Lourdes S. Santos and Mírian de Jesus Morais, for their excellent technical assistance.

\section{References}

1. ALEXIS, J. B.; DEMBROW, V. Papillary cystadenoma of a minor salivary gland. J Oral Maxilofac Surg, v. 53, n. 1, p. 70-2, 1995.

2. AQUIRRE, J. M. et al. Warthin tumor: a new hypothesis concerning its development. Oral Surg Oral Med Oral Pathol Oral Radiol Endod, v. 85, n. 1, p. 60-3, 1998.

3. BUCHNER, A.; MERRELL, P. W.; CARPENTER, W. M. Relative frequency of intra-oral minor salivary gland tumors: a study of 380 cases from Northern California and comparison to reports from other parts of the world. J Oral Pathol Med, v. 36, n. 4, p. 207-14, 2007.

4. CHAUDHRY, A. P.; GORLIN, R. J.; MITCHELL, D. F. Papillary cystadenoma of minor salivary gland origin: report of a case. Oral Surg Oral Med Oral Pathol, v. 13, n. 4, p. 452, 1960.

5. ELLIS, G. L.; AUCLAIR, P. L.; GNEPP, D. R. Surgical pathology of the salivary glands. Philadelphia: WB Saunders, 1991.

6. FOSS, R. D.; ELISS, G. L.; AUCLAIR, P. L. Salivary gland cystadenocarcinomas: a clinicopathologic study of 57 cases. American J Surg Pathol, v. 20, n. 12, p. 14407, 1996.

7. GUCCION, J. G. et al. Papillary cystadenoma of the palate: a case report and ultrastructural study. J Oral Maxillofac Surg, v. 55, n. 7, p. 759-64, 1997.

8. KERPEL, S. M.; FREEDMAN, P. D.; LUMERMAN, H. The papillary cystadenoma of minor salivary gland origin. Oral Surg Oral Med Oral Pathol, v. 46, n. 6, p. 820-6, 1978.

9. LI, L-J. et al. Clinical analysis of salivary gland tumor cases in west China in past 50 years. Oral Oncol, v. 44, n. 2, p. 187-92, 2007.

10. LOYOLA, A. M. et al. Minor salivary gland tumours: a retrospective study of 164 cases in a Brazilian population. Oral Oncol Eur J Cancer, v. 31B, n. 3, p. 197-201, 1995.

11. MAHLER, V.; SCHELL, H. Papillary cystadenoma: a rare tumor of the minor salivary glands. Eur J Dermatol, v. 5, n. 5, p. 87-9, 1999.

12. MATSUZAKA, K. et al. Papillary cystadenoma arising from the upper lip: a case report. Bull Tokyo Dent Coll, v. 44, n. 4, p. 213-6, 2003.

13. PIRES, F. R. et al. Intra-oral minor salivary gland tumors: a clinicopathological study of 546 cases. Oral Oncol, v. 43, n. 5, p. 463-70, 2007.

14. RIBEIRO, D. A.; COSTA, M. R. S. N.; ASSIS, G. F. Papillary 
cystadenoma of the minor salivary gland of the lower lip. Dermatol Online J, v.10, n. 1, p. 14, 2004.

15. SHER, L. The papillary cystadenoma of salivary gland origin. Diastema, v. 10, p. 37-41, 1982.

16. SILVA, P. J. M.; COSTA, A. S.; SILVA, A. E. O. B. Cistadenoma papilífero de língua. RGO, v. 34, n. 4, p. 319-23, 1986.

17. SIMPSON, R. H. W. Classification of tumours of the salivary glands. Histopathology, v. 24, n. 2, p. 187-91, 1994.

18. SKÁLOVÁ, A.; MICHAL, M. Cystadenoma. In: BARNES, L.; EVESON, J. W.; REICHART, P. (eds). World Health Organization classification of tumours pathology and genetics of head and neck tumours. Lyon: IARC Press, 2005.p. 273-4.

19. SOUSA, S. O. et al. Inverted ductal papiloma of minor salivary gland origin: morphological aspects and cytokeratin expression. Eur Arch Otorhinolaryngol, v. 252, n. 6, p. 370-3, 1995.
20. STOOPLER, E. T. et al. Cheilitis glandularis: an unusual histopathologic presentation. Oral Surg Oral Med Oral Pathol Oral Radiol Endod, v. 95, n. 3, p. 312-7, 2003.

21. TOIDA, M. et al. Intraoral minor salivary gland tumors: a clinicopathological study of 82 cases. Int J Oral Maxillofac Surg, v. 34, n. 35, p. 528-32, 2005.

22. TSURUMI, K. et al. Papillary oncocytic cystadenoma of palatal minor salivary gland: a case report. J Oral Maxillofac Surg, v. 61, n. 5, p. 631-3, 2003.

23. WANG, D. et al. Intraoral minor salivary gland tumors in a Chinese population: a retrospective study on 737 cases. Oral Surg Oral Med Oral Pathol Oral Radiol Endod, v. 104, n. 1, p. 94-100, 2007.

24. WILSON, D. P.; MacENTEE, M. I. Papillary cystadenoma of ectopic minor salivary gland origin. Oral Surg Oral Med Oral Pathol, v. 37, n. 6, p. 915-8, 1974.

\section{Mailing address}

Jean Nunes dos Santos Faculdade de Odontologia, UFBA Avenida Araújo Pinho, 62 - Canela CEP 40110-150 - Salvador-BA Tel.: (71) 3283-9019 Fax: (71) 3283-8962 e-mail: jeanunes@ufba.br 